\title{
TAUHID EDUCATION IN PESANTREN (Study of Tauhid Thought and Education in Pesantren al-Mukmin Ngruki, Central Java, Indonesia)
}

\author{
Din Muhammad Zakariya \\ e-mail: dinmzakariya@gmail.com
}

\begin{abstract}
Abstrak: This research aims to reveal the thoughts possessed by the kyais and ustadz in Pesantren al-Mukmin on the tauhîd education, and their implementation. The method used in this reseach was qualitative. The results of this research are as follows. Firstly, tauhîd is given a special attention since the main aim of education in the pesantren al-Mukmin Ngruki is to produce a muslim generation with pure tauhîd coloring all their lives. KH. Wahyudin and ustadz Abdurrahim Ba'asyir Lc understand tauhîd in line with Ibnu Taimiyah and Muhammad bin Abdul Wahab. Secondly, Tauhîd education in Pesantren alMukmin Ngruki using three methods of education; the doctrine of tauhîd values, understanding, and practice. Meanwhile the learning of tauhîd in the Pesantren al-Mukmin Ngruki more adopted the concept of tauhîd proposed by Muhammad bin Abdul Wahab and Ibn Taimiyah since the books studied in the halaqah program are written by Muhammad bin Abdul Wahab, while those studied in the learning of tauhîd in the class are written by Dr. Shalih Fauzan who is one of the figures in the Muhammad bin Abdul Wahab tauhîd dakwah movement in Saudi Arabia.
\end{abstract}

Kata kunci: Tauhîid, Education, Pesantren

\section{A. Introduction}

This rapid globalization flow as characterized by the swift current of information and technology turns out resulting in new problems which are often found out in individuals in a community. Juvenile delinquency, violation, sexual deviation, and various mental disorders such as depression and anxiety are the evidence that cannot be denied from negative impacts of the advancement if human civilization which is not based on strong value of faith. This then indirectly give some effects on the community's life order ${ }^{1}$.

A description of Indonesian people who are hospitable, cultured and nobly characterized has faded, but an impression that violation, and inhuman actions occurring in almost the whole country and in a long time has been created. This is due to failure of the

\footnotetext{
${ }^{1}$ Hasan, Ilmu Pendidikan Islam. (Jakarta: Media
} Karya, 2005), 23. character education developed in each educational institution. Even, It is claimed that such growing symptoms are caused by the failure in implanting the education of values ${ }^{2}$.

In the recent years, it has been warned about the importance of implanting characters in the whole learning process in education in Indonesia. Character education has attracted many attention, since the education in Indonesia has been concentrated to attain merely "grades." It can been seen from the weight of subjects focused on students' academic dimension, which is often measured from their logic-mathematics and abstraction performance (linguistic competence, memorization, abstraction or IQ), so that the produced generation is

\footnotetext{
${ }^{2}$ Muslich, Pendidikan Karakter. (Jakarta: Bumi Aksara, 2011), 136.
} 
less sensitive toany social problems in the surrounding environment ${ }^{3}$.

According to the researcher, the actual solutions to the existing problems are not on the character education, because there is something more basic namely faith or tauhid education. Faith has an important role for human being, because it is from this faith that can produce good deeds or morals in daily life. As explained by Tafsir ${ }^{4}$ that human beings are controlled by their way of life, since faith is a way of life, then human beings are controlled by their faith. So, the essence of human beings is their faith. Since the faith is in the mind, then the essence of human beings is their mind. Therefore, it is the mind which is the target of the education that should be fileld with faith.

Ulwan $^{5}$ also explains that strong faith will grow istiqamah (strong) attitude in encountering various types of tests, temptations, and challenges in life, and will result in good deeds and morals in the daily life.

In al-Quran, Surra Ibragim: 2425 , it is stated that strong faith is like a tree that has roots strongly implanted in the soil, and branches growing up the sky and that produce fruits every season. It is

Therefore, faith education should be paid attention by all the concerned parties, especially educators. The importance of raising this faith value in this life is a medium that serves as the balance for the world advancement that merely prioritizes materials, but it merely produces empty meanings, empty

\footnotetext{
${ }^{3}$ Mahmud, Pendidikan Karakter. (Surakarta: Insani Press, 2012), 29.

${ }^{4}$ Ahmad Tafsir, Ilmu Pendidikan Islami. (Bandung: Rosda, 2012), 107.

${ }^{5}$ Ulwan, Tarbiyatul Aulad. Terj. Arif Rahman Hakim. Surakarta: Insan Kamil, 2012), xvi.
}

values, especially the faith value that makes human beings lose their human meaning. However, few scientists, institutions, even high educations that develop this faith value education as one of the study, although this field of study of this faith value education is still wide and the potencies of this field may be revealed and developed.

As one of the ways to actualize this faith value, this faith value should be raised and made as the base for various aspects of life, especially in education, either at the levels of family, school, or high education in the society so that it may become an integral part of education in general ${ }^{6}$.

Tauhîd education becomes the main materials of education and missionary endeavors made by the prophets to their ummah as explained in t al-Qur'an Surah Al-Anbiya': 25, QS. Al-A'raaf: 59, QS. al-A'raaf: 65, QS. Al-A'raaf: 73, QS. Al-A'raaf: 85. The verses explain that the contents of the prophets' missionary endeavors and teachings really pay attention to the faith or tauhîd and piety, so that the education produces those with awareness that the aim of God in creating human beings in this world is to pray to Him and to become the caliph that manage this nature in accordance with God's will.

Pondok pesantren is one of Islamic education institutions of which the emphasis of the education is on the faith and piety education. in Indonesia, pesantren is an old education institution that has been close with the journey of Indonesian life since the last hundred years. It is an education institution that may be categorized as a unique institution with its own characteristics,

\footnotetext{
${ }^{6}$ Fuad, Strategi Mendidik Anak di Zaman Global. (Surakarta: Mizania, 2009), 31.
} 
so that at present it has shown its bright capability in passing various eras with the polemic of plurality. Even, in its historical journey, pesantren has given much contribution to educate the nation and to enlighten the people.

Its development and various models are related to the religious thoughts in the Islam world. The development of the pesantren itself shows some transformations of its education system and also reflects the map of religious thoughts either at the local,national or at international level where at present there are some maps of cultural diversity and some orientations of the pesantren education system influencing the formation of the santries' thoughts, ways of life and behaviors.

$$
\text { Pondok Pesantren al- }
$$

Mukmin,Ngruki, Central Java is a pesantren kown as the pesantren haraki that has graduate alumni who are militant and active in any Islam movements. The phenomenon of Pesantren al-Mukmin, Ngruki and its alumni with their various roles in the community has been seriously discussed by experts, researchers, politicians, religionists from this country or abroad.

As pondok pesantren, al-Mukmin has much contribution to teaching the piety values and understanting Islam to the people of Surakarta and the surrounding. The kain characteristic of this movement is to empasizhe the formation of moslem cadres who are ready to do Islam as a whole (kaffah) in the whole aspects of life, and to prepare the attendance of ulema with " amilin $f i$ sabîlillah", namely the ulema who do not take sides to certain groups or madzhab. Therefore, pesantren alMukmin Ngruki still plays its traditionalrole: transmiting and transfering Islamic science, and maintaining Islamic traditions.

Pesantren al-Mukmin Ngruki in creatinnf cadres of missionary endeavors refers to the understanding of salaf ulema. Some Moslems said that the step taken by Pesantren al-Mukmin Ngruki as a traditional-conservative movement, is charcaterized as hard, rigid and extreme. But its most alumni think that this step will be continued by establishing and developing new pesantrens in various places using the same understanding, although there are some alumni who continue their study either state or private higher education in this country or abroad.

Pesantren al-Mukmin Ngruki in forming the cadres really gives an emphasis on the importance ot tauhîd knowledge. It is not only as a subject at school but as a doctrine that becomes the foundation of each activity and movement of the santries. Therefore the object of the researcher's study is how the tauhîd education is implemented in Pesantren al-Mukmin Ngruki, Central Java, Indonesia.

\section{B. Research Methods}

This research was a qualitative, an approach resulted descriptive data which were in written or oral data from people and behaviors that could be observed $^{7}$.

This research aimed to answer question about what and how an occurrence and reported the results as the way they were. Through this research, it was expected it could explore the concept of the tauhîd education in Pesantren al-Mukmin Ngruki, Central Java, Indonesia.

\footnotetext{
${ }^{7}$ Moleong, Metode Penelitian Kualitatif. (Bandung: Remaja Rosda Karya, 2003), 4.
} 
In this research, the writer chose the research subject at Pesantren alMukmin Ngruki because Pesantren alMukmin make tauhî̀d as an educational base.

The research used two types of data; primary data and secondary data. The primary data were resulted from the principal and the director of Pondok Pesantren as the stakeholders. Meanwhile, the secondary data in this research were school documents such as geographical, profile, work programs of Pondok Pesantren etc.

To obtain clear, accurate and complete information, the researcher used several methods; observation, interview and documentation.

\section{Results}

\section{Thoughts of the Kyais in Pesantren al-Mukmin Ngruki on Tauhînd}

Tauhîh was paid special attention in Pesantren al-Mukmin Gruki because the main goal of education of this pesantren is to form a generation of muslims with pure piety coloring their whole life. It is in line with the Ismail Raji al-Faruqi's opinion, as told by his student, Muhammad Shafiq $^{8}$ that education should be oriented in the concept of tauhîd since tauhîd serves as a foundation made on the science and values that would be transferred into santries through educational process. Taunîd is the most important them according to Islam because this theme tells about Allah, which is notabene the central for anything. The concept of tauhîd contains further doctrinal implication that the goal of human life should be under the frame of worshipping to Allah. This doctrinal

${ }^{8}$ Shafiq, Mendidik Generasi Baru Muslim. Terj. Suhadi. (Yogyakarta: Pustaka Pelajar, 2000), 182. implication is the key word for all Islamic teachings, because it is from the concept of tauhîd that a very important standard in the Islamic education emerges, namely character standard (value standard) of which the essence is good-bad and correct-wrong. For mukmin, this value standard referred to should be very clear, namely revelation. What is instructed by Allah must be good and and what is forbidden by Allah must be bad. What is according to Allah is right, it must be right, and what is according to Allah is wrong, it must be wrong. This concept of tauhîd plays a very central role for uniting the point of views of mukminin. Therefore, Islamic education should be absolutely build on the tauhîd as its foundation.

KH. Wahyudin and ustadz Abdurrahim Ba'asyir Lc employed Ibnu Taimiyah's and Muhammd bin Abdul Wahab's method in explaining tauhîhd. It may be clearly seen when the two were describing tauhîd and its various consequences. This is also the case when they were talking about the tauhîd division into three parts: rububiyah, uluhiyah, and asma' wa shifat.

In preventing tauhîd from anything deviating such as syirik, khurafat, tahayyul and bid'ah, Pesantren al-Mukmin has a firm attitude. Such as this tauhîd ideology is a specific feature of Muhammad bin Abdul Wahab's tajdid ideology: repurifying Islamic teaching in terms of its aqidah and syariah by returning all forms of religious life to the beginning erah of Islam as practices during the Prophet Muhammad saw which is also called the golden era. Many deviations from the Islamic main teachings during the post era of the Prophet Muhammad saw are not due to less perfectness of Islam, but to less ability in catching Islam in 
accordance with the spirit of the time, and with many outer elements entering into and contradicting with Islam, so that it is necessary to make great efforts to return or to re-purify Islam to its originality. These efforts may be made by fortifying the belief in the Islamic characters, and various forms of ritual from any perverted influence.

Dealing with the attitudes towards the doers of tauhidi deviation such as adopting laws which are not coming from Allah, the researcher finds that the management of Pesantren alMukmin is divided into two typologies of tauhîd thoughts namely tauhîhd thought following (1) Muhammad bin Abdul Wahab's concept, and (2) Sayyid Quthub's.

KH. Wahyudin and ustadz Abdurrahim Ba'asyir Lc addresss the deviation based on Muhammad bin Abdul Wahab's concept, they behaved moderately towards this mater. The thoughts of the two are implemented in their attitudes towards and solutions to the existing tauhîd deviation, so that there prefer to making changes through missionary endeavors and tarbiyah.

While KH. Abu Bakar Ba'asyir is more influenced by Sayyid Quthub's concept of tauhîd thought, with his tauhîd Hakimiyah so that his missionary endeavors stated in the book Tadzkirah considers that the greatest tauhîd deviation at present is the deviation of Allah's law due to the enactment of jahiliyah laws, so that a firm attitude should be adopted and the main solution is jihad. But he develops the thought in his Jama'ah Ansharut Tauhid where he is more active in his jama'ah than in Pesantren al-Mukmin.

\section{Method and Implementation of Tauhid Education in Pesantren al-Mukmin}

a. Method of Tauhîd Education in Pesantren al-Mukmin

Pesantren al-Mukmin Ngruki in educating tauhîd to its santries adopted some methods of education. According to KH. Wahyudin, tauhîhd education in Pesantren al-Mukmin Ngruki using three methods of education; the doctrine of tauhîh values, understanding, and practice.

1) Doctrining

Tauhîd is closely related to piety a santri has as a mukmin, either his piety in Allah, His angels, His Books, His Prophets, the Judgment Day, qadha' and qadar and any other piety matters. This should be presented many times so that the santries know very well and penetrates into their heart. $\mathrm{KH}$. Wahyuddin stated that: to enable the doctrine of the tauhîhd values to penetrate into their santries' heart, the tauhîd education in the first year is to repeat the explanation of the basic principles of tauhîd, either during the tausiyah or in the classroom. We insisted that they memorize the book Ushul Tsalatsah written by Muhammad bun Abdul Wahhab, so that their tauhîd foundation is strong.

According to $\mathrm{KH}$. Wahyuddin, doctrining tauhîd values by memorizing matans on tauhîd is a way ordinarily applied in mulazamah council in Middle East, and was also applied by salaf ullemas in the past. It was told by Sahl bin Abdullah al-Tutsuri when he was still young, he was asked by his uncle to say the following sentences each time he was lying when he wanted to sleep: "Allah is with me, Allah watches me, Allah sees me." Then at some following nights, is understood the content of the 
sentences that anyone is with Allah, is felt to be watched and to be seen, does he dare to do any deviation from Him? Sahl was then known as the person with his wisdom, and was included into His good servants through his uncle who had educated and taught and implanted the meaning of piety and muraqaba since he was a child.

The aqidah doctrine in the santries is expected to be able to colour their identity and encourage them to do manhaj rabbani as given to and revealed to His Prophet Muhammad saw without any hesitation or objection. Because the consequences of piety is to do the syariah without any objection and to totally obey to Islamic teachings.

\section{2) Understanding}

According to $\mathrm{KH}$ Wahyuddin, understanding method means giving wide and deep explanations about tauhîh doctrine to santries in Pesantren alMukmin Gruki advanced tauhîhd books, and also studying verses and hadiths on faith so that the santries are expected to have faith based on satisfactory evidences and argumentations.

The explanations are also intended to open their minds on Allah's power that is full of miracles. Their full minds certainly will result in preoccupation and submission to the greatness of Allah swt. Each soul with this feeling will also feel some piety and muraqabatullah (feeling of being watched by Allah swt). One will feel some serenity in mind and enjoyment in observance and sweetness in praying to Allah Rabb of the universe.

3) Practicing

Practicing method means, according to $\mathrm{KH}$. Wahyuddin: that after the santries master the tauhîd doctrine and understand the explanations, they are guided to practice of what they had been able to practice in the Pesantren. The evidence of one's strong tauhîd is one's diligence and preoccupation in worshiping and good character and appearance. Therefore, we would warn and punish santries who are lazy to worship, and are not wear neat clothes when they are praying, remind them to Allah when they break the laws, and punish them from all tauhîd deviations they do. These need modeling and supervising from the ustadzs. The santries are also habitualized with tauhid pray (dzikir) so that an environment as Allah's servants who always remember Allah all the time, and where parts of their bodies are busy with praying to Allah and their minds are full of rabbani character may be created.

According to $\mathrm{KH}$. Wahyuddin, in practicing tauhid, sacrifice is needed. Therefore, to grow the sacrifice mind, stories on the Prophet Muhammad's and his comrades' sacrifices are often presented to them and the santries are ask to read books on the sacrifice.

\section{b. Tauhîd Learning in Pesantren Al- Mukmin Ngruki}

According to $\mathrm{KH}$. Wahyuddin and ustad Abdurrahim Ba'asyir Lc, correct aqidah is aqidah Ahlu sunnah wal jamâ'ah as taught by the Prophet saw in Qur'an and Sunnah. In the Ahlu sunnah wal jamâ'ah school, two madzhabs are identified: as-salaf that is usually represented by Imam Ahmad bin Hanbal and Ibnu Taimiyah, and alkhalaf represented by al-Asy'ari and alMaturidi. The difference between the two lies in the scheme, where as-salaf precedes naql than mind, while al-khalaf harmonizes between naql and mind. Assalaf does not describe naql, while alkhalaf does. 
In Madrasah Kuliyatul Mu'allimin (KMI), the santries in general were taught tauhî̀d faith using the ahlu sunnah wal jamâ'ah madzhab with as-salaf school, with the objective that they would have strong Islamic faith, believe in six pillars of faith, understand shahih dalil dealing with the faith, and not being influenced by perverted belief.

At the beginning of Pesantren alMukmin Ngruki, the learning curriculum of faith followed that of Pesantren Gontor because KH. Abu Bakar Ba'asyir and $\mathrm{KH}$. Wahyudin are the alumni of the pesantren. Therefore, the faith learning in Pesantren al-Mukmin Ngruki, made use of Ushuluddin book written by KH. Imam Zarkasy where the description of the faith matter is more focused on Asy'ari madzhab. While in the reference books namely Risalah Tauhîd written by Muhammad Abduh, al-Sanusiyah by Abu Abdullah Muhammad bin Yusuf, Qathr al-Ghaits by -Nawawi, alHasyiyah al-Sanusiyah by Muhammad al-Dasuki, mauqif al-basyar tahta sulthah al-qadha' wal qadar by Musthafa Sabri, jawahir al-Tauhîd by Ibrahim bin Muhammad al-Bajuri were used. But in 1990, after the arrival of some alumni and pesantren cadres from thalabul ilmi in some education institutions, either domestic or oversea, such as LIPIA Jakarta, Jami'ah alIslamiyah Madinah, Jami'ah Umul Qura Mecca, Jami'ah al-Iman Yemen, the curriculum in KMI Pesantren al-Mukmin started being changed, following the concept of faith proposed by Muhammad bin Abdul Wahab.

1) Tauhîid Learning in the classroom

a) Tauhîid Learning At Grade One at KMI
According to ustadz Abdurrahim Ba'asyir Lc, the tauhîd learning at the first grade used a book Tauhîd written by Syaikh Dr. Shalih bin Fauzan AlFauzan, First Volume and was supported by some reference books such as Aqîdah al-Wasithiyah, al-Risâlah alTadmuriyah, al-'Ubûdiyah, Ma'ârij alWushûl ila anna al-Rasûl qad bayyana al-furû' wal Ushîl written by Syaikhul Islam Ibnu Taimiyah, Kitab Taunî̀d by Muhammad bin Abdul Wahab, 'Aqa'id al-salaf by Ali Saami al-Nasysyar, and fi al-aqîdah al-islamiyah baina alsalafiyah wa al-mu'tazilah by Mahmud Ahmad Khafaji.

This learning is more focused on six items:

1. The understanding of faith and its urgency

2. Sources of right faith

3. Deviation of faith and the way to prevent it

4. Taunî̀d Rububiyah

5. Tauhîd Uluhiyah

6. Tauhîd Asma' wa Shifat.

b) Tauhîd Learning at Grade two at KMI

Ustadz Abdurrahim Ba'asyir Lc explained that the second grade santries used Tauhîd books written by Syaikh Dr. Shalih bin Fauzan Al-Fauzan Second Volume, supported by some referent books such as Aqîlah al-Wasithiyah, kitab al-îman, al-Nubuwat, iqtidhâ' shirâth al-mustaqîm all of which were written by Syaikhul Islam Ibnu Taimiyah, and by Tauhî̀d book written by Muhammad bin Abdul Wahab.

The tauhîd learning at the second grade is more focused on seven items:

1. The nature of Belief

2. Belief in Allah

3. Belief in Allah's Angels

4. Belief in Allah's Books 
5. Belief in the Prophets

6. Belief in Hereafter

7. Belief in qadha' dan qadar.

c) Tauhîid Learning at Grade three at KMI

According to ustadz Abdurrahim Ba'asyir Lc, the faith learning at grade three used Tauhîd book written by Syaikh Dr. Shalih bin Fauzan Al-Fauzan Volume Three and supported by some referent books such as al-majmu' alfatâwâ, al-furqân baina al-haq wa albâthil, al-furqân baina auliyâ' arRahmân wa auliyâ' asy-syaithân, qấidah jalîlah fi al-tawassul wa alwasîlah written by Syaikhul Islam Ibnu Taimiyah, Kitab Tauhî̀ by Muhammad bin Abdul Wahab, al-ibdâ' fi madâr alibtidâ' by Ali Mahfudz.

The tauhîd learning at this grade three is more focused on six items:

1. Syirik

2. Kufur

3. Nifâq

4. Bid'ah

5. Sihir, shamanism, and prophecy

6. Glorifying tombs

2) Tauhîd Learning out of the classroom

To deepen the santries' understanding of tauhîd, the Pesantren held some scientific activities, among others are as follows:

\section{a) Faith Halaqah}

It was held in the mosque in the pondok after Subuh praying. The books studied in this halaqah were as follows:

1. al-Ushûl al-Tsalâtsah

2. al-Qawâ'id al-arba'

3. Kasyfu syubuhât

4. Masâ'il al-Jahiliyah

5. Tauhîd

b) Taw'iyah Diniyah

This program was held on each Tuesday after Maghrib praying. The topics discussed in this program were around faith matters. On Tuesday in the odd week the program was held by ustadz Abdurrahim Ba'asyir Lc, while in the even week, by some ustadzs alternately.

In the study on Tuesday in the odd week, us ustadz Abdurrahim Ba'asyir Lc discussed about schools deviating from the faith scheme of ahlu sunnah wal jamaah such as khawarij, syi'ah, murji'ah, qadariyah, jabariyah, mu'tazilah, jahmiyah, asy'ariyah, maturidiyah, ibadhiyah, isma'iliyah, bathiniyah, qaramithah, mysticism, philosophy and other schools of thoughts.

The method of tauhîd education applied by Pesantren al-Mukmin Ngruki is in line with what is formulized by Suwaid $^{9}$ that the parents or educators should pay attention to their children's taunîd and dictate it since the children are in childhood so that the children grow with the faith. The first step is to give them memorization, then, understanding, belief ( $i$ 'tiqad), faith, and djustification. This is easy to di since human beings are born at the condition of fitrah (holy) and Allah vacates human hearts to accept faith at their beginning growth without any argumentation or real evidence.

The concept of tauhîd education applied in Pesantren al-Mukmin is also in line with that proposed by Ulwan in his book Tarbiyah al-Aulad. Ulwan ${ }^{10}$ explained that the tauhid education is aimed at binding childen with basic beliefs, the pillars of Islam, and syariat bases since their childhood. What is meant by basic beliefs is anything

\footnotetext{
${ }^{9}$ Suwaid, Manhaj al-Tarbawiyah al-Nabawiyah li al-Thifl. Terj. Salafuddin Abu Sayyid. (Solo: Pustaka Arafah, 2016), 111-113.

${ }^{10}$ Ulwan, Tarbiyatul Aulad. Terj. Arif Rahman Hakim. Surakarta: Insan Kamil, 2012), 111-129.
} 
determined through right telling on the nature of belief, supernatural matters such as belief in God, Angels, samawiyah books, all prophets, two questions asked by the angel in the hereafter, punishment hereafter, revival, hisab (court), the heaven, the hell, and all supernatural matters.

What is meant by the pillars of Islam is all liturgies of parts of the body and treasures, such as praying, fasting, alms, haj for those who are able to do. The syariat bases are each matter that may accompany someone to the rabbani schema, Islamic teachings either the faith, worship, character, law, rules and provision.

An educator should teach the children the guidance in the form of the faith education since they are childhood. He should also teach foundations in the form of Islamic teachings so that they will be bound with Islam religion in terms of faith and worship, besides the application the the method and rules. They will not know anything except that Islam is their religion, Al-Quran is their guide, and the Prophet saw as their leader and model.

But according to the researcher, the practice of tauhîd education applied in Pesantren al-Mukmin is more completed and structure than what is suggested by the two experts in education. The tauhîd learning applied in the pesantren used two learning systems, classical and halaqah.

Classical learning system is the one adopted in each classroom in accordance with the grade using books that have been determined in the curriculum of the pesantren namely Tauhîd book written by Dr. Shalih Fauzan and some supporting books by Ibn Taimiyah. This, according to the researcher, will give some width in understanding tauhhid, so that the santries will be able to understand tauhîd in the order and also to be familiar with reference books on tauhîid.

Meanwhile the tauhîd learning using the halaqah method held in the mosque is made by memorizing and studying the content of the book written by Muhammad bin Abdul Wahab such as Ushul Tsalâtsah, qawâ'id arba', kasyfu syubuhât and kitâb tauhîd. This, according to the researcher, will provide the santries with deep understanding of tauhîd, so that they will have strong understanding of tauhît since they have to memorize the content of the books and to memorize the theorems around tauhîid.

The tauhîd learning in Pesantren al-Mukmin Ngruki, according to the researcher, followed the tauhîd concept of Muhammad bin Abdul Wahab and Ibn Taimiyah since the books studied in the halaqah program are written by Muhammad bin Abdul Wahab. Meanwhile the books studied in the tauhîd learning in the classroom are written by Dr. Shalih Fauzan, one of the figures in the missionary endeavor movement in tauhîd proposed by Muhammad bin Abdul Wahab in Saudi Arabia.

Tauhîd learning according to the concept proposed by Muhammad bin Abdul Wahab, according to the researcher, will result in tauhîh character as follows:

1) Possessing the comprehensive and moderate understanding of tauhîd

As explained in the previous discussions, the concept of tauhîd proposed by Muhammad bin Abdul Wahab divides tauhîd into three namely rububiyah, asma' wa shifat, and uluhiyah. Oneness of Allah in His or rububiyah tauhîd means oneness of 
Allah as the real Creator, the absolute Ruler, the Regulator of the universe, and the Provider of sustenance to all His creatures. It means that no real creator, ruler, regulator, sustenance giver exists, except Allah, and no one is able to make something alive and dead, except Allah.

The oneness of Allah dealing with the names and His characteristics or asma' wa shifat tauhîd asma' wa shifat means believing the oneness of Allah in each His Characteristic and name He has given in Himself, as stated in either alQur'an or as Sunnah. It means that His names and characteristics are not refused, His characteristics are not considered the same those of His creatures, His meaning is not changed, and His nature is not asked.

The oneness of Allah in terms of uluhiyah of Allah or uluhiyah tauhîd means that onenoness of Allah in all forms of liturgies either in words or acts, inner or outer words andacts should be intended to Allah only. Uluhiyah tauhî̀d is the reverse of rububiyah tauhîd, since rububiyah deals with Allah's acts, while uluhiyah with servants' acts.

This kind of understanding of tauhhid, according to the researcher, will make santries comprehend tauhîd completely. The santries will really know rububiyah tauhîd that was applied by the pagans that broke uluhiyah tauhîd principles so that they were trapped into syirik and khurafat acts. Moreover, the santries will really understand asma'wa shifat tauhîd so that they will not deviate in their understanding of any stipulations (nash) dealing with Allah's names and characteristics. This deviations really happened to Mutakallimin people.

2) Possessing anti- syirik and bid'ah Attitudes
In his movement in the missionary endeavor of tauhîh, Muhammad bin Abul Wahab really opposes any syirik and bid'ah because the two are the opponents of tauhîd, since tauhîd demands to the oneness of Allah in our worship and makes the Prophet Muhammad saw as the reference in worshipping to Allah.

This kind of such an understanding according to the researcher will form attitudes of no syirik and bid'ah. This happened to in Pesantren al-Mukmin as stated by Ustadz Abdurrahim Ba'asyir Lc that repeating explanations on tauhid and their cancelations either in the classroomor during the tausiyah in the mosque will give a strong foundation to the santries' understanding of tauhîd.

Pesantren al-Mukmin educated its santries to show firm attitudes towards any syirik because this pesantren viewed that syirik is very dangerous and its influence would be feld by the doers either in the world or in hereafter.

Dealing with bid'ah, namely whorship that does not have any law and is not modeled or done by the Prophet Muhammad saw, including the addition or reduction of the worship. All bid'ah in religion matter is despicable. Pesantren al-Mukmin is always trying to prevent its santries from all bid'ah in the form of faiths or practices.

3) Possessing critical attitudes towards any charity

Muhammad bin Abdul Wahab is figure of renewal when the ummah are trapped in the deviation of thinking and practices of worship. Therefore, the concept of tauhîh proposed by Muhammad bin Abdul Wahab forms critical persons in terms of faiths and worship. Anything without shahih basis should be left. 
According to the observations made by the researcher, the taunîh elarning in Pesantren al-Mukmin following the tauhîd concept proposed by Muhammad bin Abdul Wahab may produce santries with critical attitudes especially when they found something improper among the community dealing with faqith, practices of worship and cultures. Ustadz Abdurrahim Ba'asyir Lc stated that cultural is human work, therefore, it should be examined whether there are something in contradiction with syariat or not. If it is contradicted with syariat, it is syariat that should be given priority.

4) Posessing clear Wala' dan Baro' attitudes

Wala' and baro' is part of consequences of tauhîd coming from some understanding the sentence lâ ilâha illallah meaning "there is no god but Allah." Therefore, one denies ilahiyah (deity) from except Allah and determines it merely for Allah.

Form the sentence spoken by the Prophet Muhammad saw, it means that one should purify any obedience and leave any prohibions as instructed by the Prophet.

Therefore the sentence lâ ilâha illallah means baro' dan wala' (refuse and determine), wala' to Allah, His religion, Books, His Prophet's sunah, and His shalih servants, baro' any thaghut, worshiped except Allah, as stated in His commandment (Qs. AlBaqarah: 256).

It is the tauhîd principle that is taught in Pesantren al-Mukmin Ngruki that makes the santries possess clear Wala' dan Baro' attitudes, although the muamalah principles with the makruf way are always taught so that they santries may be able to live among the community while they are still keep the baro' and wala' principles.

\section{Discussion}

Theoretically, faith or tauhîd education is solution to the problem of moral crises, since the concept of tauhîd contains doctrinal implications that the aim of human beings should under the framework of worshiping Allah. It is this doctrine that is the keyword for all Islamic teachings, because this concept of tauhîd will produce a character (value) standard of which the essence is good-bad, and right-wrong. For mukmins, the value standard to refer to should be very clear, namely revelation. what is ordered by Allah must be good, and what is is forbidden by Allah must be bad. What is right according to Allah must be right and what is wrong must be wrong. The concept of tauhîd plays a very central role as the unifier of the point of view of all mukminins. As a result, Islamic education absolutely must be build above the tauhîd as its foundation. Tauhîh education should adopt a method of doctrine of tauhîd values since tauhîd deals with beliefs possessed by a sentry as mukmin, either in Allah, His Angels, Books, Prophets, hereafter, qadha' and qadar and other matters of belief. It should be repeatedly conveyed so that the santries know by heart and may implant it in their heart. It is then continued with the method of understanding, giving wide and deep explanations about the doctrines of tauhîd by studying advanced books on tauhîld, and also supporting the doctrines with verses and hadits on faith so that the santries will have strong faith with satisfactory evidence and argumentation. The next method of tauhid education is the method of guidance in practicing tauhîhd values. 
This finding is in line with the theory of tauhîd education as stated by Suwaid that tauhîd education is the main pillar in children education so that tauhîd should be dictated to children from their childhood with the hope that they will be able to grow with the faith. The first step is to give them some recitations, the understandings, and belief (I'tiqad), faith, and justification.

Typologically, this research finds three typologies of tauhîd understanding. First, tauhîd according to the mutakallimin people is merely to believe in Allah, namely they believe in the oneness of Allah in Hiss all act since it is Allah himself who creates all creatures, who gives sustenance for each human being, animal and other creatures, and who order the universe. The kind of tauhîd discussed by this group is rububiyah of Allah, they do not pay attention to uluhiyah of Allah. The understanding of tauhîd of this kind is followed by liberal people, since this kind of tauhîd is recognized all people.

Second, tauhîid according to Ibn Taimiyah and Muhammad bin Abdul Wahab, means believing in the oneness of Allah in anything becoming His specificity, namely in terms of His rububiyah, asma' wa shifat, dan uluhiyyah Allah. The oneness of Allah in terms of His rububiyah-Nya or rububiyah tauhîd means recognizing of the oneness of Allah as the real creator, absolute ruler, regulator of the universe, and provider of sustenance to all His creatures. It means that there is no real creator, ruler, regulator, and provider except Allah, and there is no one that may make something alive or dead except Allah. The oneness of Allah dealing with His names and characteristics or asma'wa shifat tauhid means believing in the oneness of Allah in each characteristic and name Allah has given to Himself, either in al-Qur'an or in as-Sunnah. It means that the names or the characteristics are not refused at all, Allah is not be likened with the characteristics of His creatures, His meanings are not denied, and His nature is not asked. The oneness of Allah in terms of His uluhiyah or uluhiyah tauhîd means believing in the oneness of Allah in terms of all types of worships in the word and attitude, inner or outer, should be merely oriented into Allah. Uluhiyah tauhîd is the consequence of rububiyah tauhîd and this tauhîd demands the existence of rububiyah tauhîd. The understanding of tauhîd according to the concept proposed by Muhammad bin Abdul Wahab forms moderate and comprehensive attitudes towards the understanding and practicing of Islam.

Third, tauhîd according to Sayyid Quthub means making the oneness of Allah in terms of worship, especially in legal matters, or hakimiyah tauhîd. He emphasizes this hakimiyah taunîld because according to him, the greatest idolatry is in the legal matter namely the man-made laws that do not refer to al-Qur'an and Sunnah. The main materials in the tauhîd learning are khilafah, adopting any laws according to God's laws, jahiliyah and thaghut. The understanding of tauhîd according to the Sayyid Quthub's concept, forms radicalism and an easy way to say kafir to those deviating from tauhîh.

This finding complement the finding in Amal Fathullah Zrkasy's research that merely studies the concept of tauhîd proposed by Ibn Taimiyah and its influence in Indonesia, especially in Pesantren Darussalam Gontor.

\section{E. Conclusion}


Based on the research described, it can be concluded that: (1) Tauhît is given a special attention since the main aim of education in the pesantren alMukmin Ngruki is to produce a muslim generation with pure tauhîh coloring all their lives. (2) there are two types of tauhîd adopted in this Pesantren. KH. Wahyudin and ustadz Abdurrahim Ba'asyir Lc understand tauhîtd in line with Ibnu Taimiyah and Muhammad bin Abdul Wahab. It may be clearly seen when they were explaining that tauhîd is divided into three parts namely rububiyah, uluhiyah and asma' wa shifat. Meanwhile $\mathrm{KH}$ Abu Bakar Ba'asyir is more influenced by the understanding of tauhîd suggested Sayyid Quthob with the implication that it is more focused on Hakimiyah tauhîd. The second implication from such an understanding is in viewing any deviation from the consequence of the taunîd in any problems which are not punished by God's law. KH. Wahyudin and ustadz Abdurrahim Ba'ashyir were more moderate and more careful in saying the word "kafir" (heathen) to the doer, but were employing the solution of "dakwah" and "tarbiyah", while KH. Abu Bakar Ba'asyir easily said "kafir" to the doer and gave the solution of "jihad". (3) Tauhîhd education in Pesantren al-Mukmin Ngruki using three methods of education; the doctrine of tauhîd values, understanding, and practice. Meanwhile the learning of tauhîd in the Pesantren al-Mukmin Ngruki more adopted the concept of tauhîd proposed by Muhammad bin Abdul Wahab and Ibn Taimiyah since the books studied in the halaqah program are written by Muhammad bin Abdul Wahab, while those studied in the learning of tauhid in the class are written by Dr. Shalih Fauzan who is one of the figures in the Muhammad bin Abdul Wahab tauhîd dakwah movement in Saudi Arabia.

\section{References}

Al-'Aq1, N.A.K. (2014). Hanya Islam bukan Wahhabi. Bekasi: Darul Falah.

Al-Ajlani, M. (2012). Kasyful Khafa'. Riyadh: Dar Ibn Hazm.

Azizy, A.Q.A. (2000). Islam dan Permasalahan Sosial; Mencari Jalan Keluar. Yogyakarta: Pustaka Pelajar.

Baswedan, S. (2008). Tauhid Beres Negara Sukses. Jakarta: Akbarmedia.

Creswell, J.W. (2013). Reseach Design: Pendekatan Kualitatif, Kuantitatif, dan Mixed. Terj. Achmad Fawaid. Yogyakarta: Pustaka Pelajar.

Daradjat, Z. (1992). Ilmu Pendidikan Islam. Jakarta: Bumi Aksara.

Departemen Pendidikan Nasional (2002). Kamus Besar Bahasa Indonesia. Jakarta: Gramedia.

Departemen Agama RI (2001). Pola Pembelajaran di Pesantren. Dirjen Bimbingan Islam, Proyek Peningkatan Pondok Pesantren.

Fuad, A. (2009). Strategi Mendidik Anak di Zaman Global. Surakarta: Mizania.

Al-Ghazali (1972). al-Iqtishad fil

I'tiqad. Mesir: al-Junaidiyat.

Al-Hakami, H.A. (2003). Ma'arij alQabul. Kairo: Dar Ibnu alHaitsam.

Al-Hakkari, A.H. (2001). I'tiqad Imam Syafii. Mekah: Maktabah alAsadiah.

Hasan, A. (2005). Ilmu Pendidikan Islam. Jakarta: Media Karya. 
Al-Hazimi, K. (2000). Ushûl alTarbiyah al-Islamiyah. Madinah Munawwarah: Dar 'Alam al-Kutub.

Al-Hissi, S.M. (2009). Daur al-Mar'ah al-Muslimah fi Tarbiyah Abna'iha. Gaza: Jami'ah Islamiyah.

Ibnu Katsir (1998). Tafsir al-Qur'an alAdzim, Kairo: Mathba'ah asySya'b.

Ibn Taimiyah (1982). Dar'ut Ta'arud al'Aql wa al-Naql. Riyadh: Jami'ah al-Imam al-Islamiyah. (1404H). Majmu' Fatawa. Mekah: Maktabah an-Nahdhah al-Haditsah. . (1980). Minhaj as-Sunnah al-

Nabawiyah. Kairo: Dar alMa'rifah.

(1432H). al-Risalah alTadmuriyah. Kairo: Matba'ah alSalafiyah.

Imarah, M. (2006). Fitnah al-Takfir. Kairo: Wizarah al-auqaf alMishriyah.

Al-Jauziyah, I.Q. (2011). Ighatsat allahfan. Terj. Hawin Murtadha. Solo: al-Qowam.

(1982). Madarij al-Salikin. Kairo: al-Hayah al-Mishriyah al-'Ammah lil kitab.

(1995). al-Tibyan fi Aqsam alQur'an. Beirut: al-Maktabah al-Islamiyah.

(1398H). al-Qasha'id alNuniyah. Pakistan: Idarah Turjuman as-Sunnah.

Al-Khumaisi, M. (2001). I'tiqad Aimmah al-Salaf. Riyadh: Maktabah al-Ma'arif.

Langgulung, H. (1992). Asas-Asas Pendidikan Islam. Jakarta: Pustaka Al-Husna.
(1980). Beberapa Pemikiran tentang Pendidikan Islam. Bandung: al-Ma'arif.

Mahmud, A.H. (2012). Pendidikan Karakter. Surakarta: Insani Press.

Mahmud, A. (2009). Pesantren dan Pergerakan Islam. Solo: alMukmin Press.

Al-Maududi, A.A. (1397H). Mabadi' alIslam. Beirut: Mu'assasah alRisalah. ...(1967). Islamic Way of Life. Terj. Usman Raliby. Jakarta: Bulan Bintang.

Moleong, L.J. (2014). Metode Penelitian Kualitatif. Bandung: Remaja Rosda Karya.

Muslich, M. (2011). Pendidikan Karakter, Jakarta: Bumi Aksara.

Najjar, R.A. (2009). Malâmih alTarbiyah al-Dzatiyah fi Dhau' al-Fikr al-Tarbawi al-Islami. Gaza: Jami'ah Islamiyah.

Nasr, S.H. (1987). Traditional Islam in the Modern World. Kuala Lumpur: Foundation for Traditional Studies.

Al-Nasysyar, A.S. (1981). Nasy'ah alFikr al-Falsafi fil Islam. Kairo: Dar al-Ma'arif.

Nata, A. (2011). Sejarah Pendidikan Islam. Jakarta: Kencana Prenada Media Grup. .(2003). Kapita Selekta Pendidikan Islam. Bandung: Angkasa.

.(2005). Filsafat Pendidikan Islam. Jakarta: Gaya Media Pratama.

Al-Qahthani, M.S. (1994). Memurnikan laa ilaaha illallah. Terj. Abu Fahmi. Jakarta: Gema Insani Press. 
(2005). al-Wala' wal-Bara' fil Islam. Mekah: Dar at-Tauzi' wan Nasyr al-Islamiyah.

Qardhawi, Y. (1980). Pendidikan Islam dan Madrasah Hasan alBanna. Terj. Bustani A. Gani dan Zainal Abidin Ahmad. Jakarta: Bulan Bintang.

Quthub, M.I. (1415 H). Laa ilaaha illallah Aqidah wa Syari'ah wa Minhaj Hayat, Kairo: Dar Syuruq.

Quthub, S. (2011). Ma'alim fi al-Thariq. Terj. Mahmud Harun. Yogyakarta: Uswah.

Rahardjo, D. (1993). Ensiklopedi Islam. Ulumul Qur'an, IV, No. 3.

Ramadhan, M.S. (2005). al-Salafiyah Marhalah Zamaniah Mubaarakah Laa Madzhab Islam. Beirut: Darul Fikr.

Al-Ruwaisyid, A. (2013). alWahhabiyah Harakah al-Fikri wa al-Daulah. Riyadh: Dar Ibn Hazm.

Shafiq, M. (2000). Mendidik Generasi Baru Muslim. Terj. Suhadi. Yogyakarta: Pustaka Pelajar.

Shafwan, M.H. (2014). Intisari Sejarah Pendidikan Islam. Surakarta: Pustaka Arafah.

Shalih (1426). al-Tarbiyah al-Islamiyah Mushthalah wa Mafhum. Abha: tt.

Al-Sili, S.A.A. (1993). Al-Aqidah alSalafiyah Baina Imam Ibn Hambal dan Imam Ibn Taimiyah. Kairo: Dar al-Manar.

Suwaid, M. (2016). Manhaj alTarbawiyah al-Nabawiyah $l i$ al-Thifl. Terj. Salafuddin Abu Sayyid. Solo: Pustaka Arafah.

Al-Syaibany, O.M.T. (1979). Falsafah Pendidikan Islam. Terj. Hasan Langgulung. Jakarta: Bulan Bintang.
Tafsir, A. (2010). Filsafat Pendidikan Islam. Bandung: Rosda. .(2012). Ilmu Pendidikan Islami. Bandung: Rosda.

Ulwan, A.N. (2012). Tarbiyatul Aulad. Terj. Arif Rahman Hakim. Surakarta: Insan Kamil.

Wahab, M.A. (2004). al-Durar alSunniyah. Riyadh: Dar Ibn Hazm.

(2007). al-Rasail alSyakhsyiyah. Riyadh: Dar Ibn Hazm.

Yasir, A.A. (2012). Menjadi Ahli Tauhid di Akhir Zaman. Surakarta: Granada Mediatama. 